\title{
SETBP1 Geninde Mental Retardasyon Tip 29 Sendromuyla Ilişkili Yeni Mutasyon Tanımlanması: Olgu Sunumu
}

Identification of a New Mutation in SETBP1 Gene Related to Mental Retardation Type 29 Syndrome: Case Report

Meryem Alagöz, Ezgi Günger, Adnan Yüksel

Biruni Üniversitesi Mühendislik ve Doğa Bilimleri Fakültesi, Moleküler Biyoloji ve Genetik Bölümü, İstanbul

Yazı̧ıma Adresi / Correspondence:

Meryem Alagöz

Biruni Üniversitesi, Mühendislik ve Doğa Bilimleri Fakültesi, Moleküler Biyoloji ve Genetik Bölümü, İstanbul, Protokol Yolu No: 45, 10. Y1l Cd., 34010 Zeytinburnu/İstanbul T: +905530767688 E-mail: malagoz@biruni.edu.tr

Geliş Tarihi / Received : 08.08.2019 Kabul Tarihi / Accepted : 11.11.2019

Orcid:

Meryem Alagöz https://orcid.org/0000-0002-6243-2146

Ezgi Gunger https://orcid.org/0000-0001-8342-2150

Adnan Yüiksel https://orcid.org/0000-0002-7275-8254

( Sakarya Tip Dergisi / Sakarya Med J 2019, 9(4):715-720 ) DOI: 10.31832/smj.589375

Öz

Mental retardasyon genetik ve çevresel faktörlerin etkileri sonucu ortaya çıkan konjenital anomalilerdir. Genetik bozuklukların mental retardasyonun gelişmesindeki etkinliği göz önüne alındığında genetik tanının hastalığın teshisi ve tedavisideki rolü büyük önem taşımaktadır. Mental retardasyonda erken dönemde teșhis koyulması ve müdahale edilmesi durumunda hastalığın seyrinin daha olumlu yönde gitmesi sağlanabilir ve tedavisinde büyük farklar yaratılabilir. Bu olgu sunumunda yeni nesil dizileme yöntemi (YND) kullanılarak hastanın tüm genomundaki protein kodlayan genler dizilenmiştir ve klinik bulgularla ilişkili olarak SET bağlayıcı protein 1'in (SETBP1) geninde daha önce tanımlanmamış heterozigot, klinik etkisi henüz bilinmeyen bir mutasyon c.3515G>T saptanmıştır. Hastada bulunan bu yeni mutasyon Sanger dizileme ile doğrulanmıștır.

Anahtar Mental retardasyon; SETBP1; Yeni nesil dizileme (YND); Tüm Exom Dizileme

kelimeler

Abstract

Mental retardation is a congenital anomaly caused by the effects of genetic and environmental factors. Since the impact of genetic abnormalities in the development of mental retardation, genetic testing has great importance in the diagnosis, treatment and prognosis of the disease. In case of early diagnosis and intervention in mental retardation, the course of the disease can be improved in a more positive way and major differences can be made in the treatment. In this case, the sequencing of protein-coding genes within the whole genome of the patient revealed the autosomal heterozygous dominant mutation in the SETBPI gene, which is found to be associated with clinical findings of the patient. This new mutation is confirmed by Sanger sequencing

Keywords Mental retardation; SETDB1; Next Generation Sequencing (NGS); Whole Exom Sequencing 


\section{GIIRIŞ}

Konjenital anomaliler, doğuştan gelen kusurlar olarak bilinen ve bireylerin sağlı̆̆ını, gelişimini, yaşamını etkileyen doğum öncesi kökenli hastalıklardır. ${ }^{1}$ Zihinsel gelişim bozukluklarıyla birlikte görülen mental retardasyon (MR) konjenital anomalilerdir ve etkilenen bireyde öğrenme, adaptif davranış gibi bilişsel işlevlerin önemli bir şekilde bozulmasina sebep olur.

Mental retardasyon genetik ve sonradan oluşan nedenleri içeren çoklu risk faktörleriyle bağlantılıdır. Genetik olmayan nedenler doğum öncesi, gebeliğin son dönemi, doğum sonrası ve çevresel faktörleri içerir. Raporlanan en yaygın doğum öncesi anneye bağlı risk faktörleri astım, diyabet, hipertansiyon, böbrek hastalıkları ve epilepsidir.

Temel perinatal faktörler ise düşük doğum kilosu, erken doğum, doğum komplikasyonları, doğum enfeksiyonlarıdır. Doğum sonrası enfeksiyonlar, civa, kurşun gibi toksiklere maruz kalma, gelişimsel bozukluklar, merkezi sinir sistemi tümörleri ve kronik şiddetli yetersiz beslenme şeklinde raporlanmıștır. ${ }^{2.3}$

Genetik faktörler, mental retardasyon vakalarının \%30-50'sinin temel nedenleri arasındadır. Genetik nedenler arasında en yaygın olanları gen defektleri ve kromozom hastalıklarıdır. Kromozom anomalileri sayısal ve yapısal olmak üzere iki temel grupta değerlendirilebilinen ve genetik faktörler içinde en iyi tanımlanan gruptur. Gen defektlerinde ise tek gende oluşan bir mutasyon mental retardasyonun çoğunlukla biyolojik mekanizmasına müdahale etmektedir. Bu gen tarafından kodlanan proteinin işlevsiz olması sonucu hücresel bağlantılar, sinaptik yapı veya işlevi etkileyen fonksiyonel hücresel yolaklar etkilenir. Bu yaygın genetik ve fizyopatolojik mekanizmanın sonucu olarak, serebral kompleks fonksiyonları bozulmakta ve bilgiyi işlemedeki yetenekler sınırlanmaktadır. Mental retardasyon ile ilişkili genlerin sınıflandırılmasında iki kategori göz önünde bulundurulabilir: bunlardan biri beyin gelişiminde rol oynayan genler, nörogenez ve nöronal göç- tür. Bunlardan bazıları beyin malformasyonu nedeniyle ikincil bir semptom olarak kabul edilebilir. Diğer kategori ise belirgin beyin anomalileri olmadan mental retardasyon kondisyonlarından sorumlu genlerdir. Mental retardadyon ile ilişkili genlerin listesi gittikçe büyümektedir. X’ e bağlı mental retardasyon tipleri tüm tipler arasında \%20 gibi bir orana sahiptir. Bu tiplerdeki bilinen mutasyonların çoğu, fonksiyon kaybı mutasyonlarıdır. X' e bağlı olarak tanımlanan ve en yaygın olan tek gen anormalliği frajil $\mathrm{X}$ sendromuna neden olan FMR1 genidir.4 İntraselüler sinyal mekanizmasinda rol oynayan GDI1, OPHN1, PAK3, RPS6KA3, IL1RAPL ve TM4SF2 gibi birçok gendeki mutasyonların da X'e bağlı mental retardasyonla ilişkisi olduğu düşünülmektedir.5 CRBN, TUSC3, DYNC1H1 gibi birçok gendeki mutasyonlar ise nonsendromik otozomal geçişli mental retardayon tipleriyle ilişkilendirilmiştir..$^{6-8}$

SETBP1 geni, SET bağlayıcı protein 1'in kodlanması talimatlarını içerir. Kodlanan proteinin, DNA replikasyonuna katılan SET nükleer onkojenini bağladığı bilinmektedir. SETBP1 proteinin başta beyinde olmak üzere birçok dokuda aktif olduğu gözlemlenmiştir. Bu proteinin tam işlevi kesin olarak anlaşılmamıştır, ancak SET bağlayıcı protein l'in, beyin hücrelerinin gelişiminde ve işlevinde son derece önemli bir rolü olabileceği öngörülmektedir., ${ }^{9,10}$

$\mathrm{Bu}$ çalışmada ailede akraba evliliği bulunmayan, klinik olarak zihinsel engelli tanısı konulan hastada, hastalığın genetik sebebinin araştırılmasının detaylı yapılabilmesi için Tüm Ekzom Dizi yapılmıştır. Tüm Ekzom Dizi sonucunda tespit edilen varyantların hastanın klinik bulguları ile olan ilişkisi biyoinformatik yöntemler kullanılarak araştırılmıştır.

\section{OLGU SUNUMU}

Atipik otistik davranış, gecikmiş konuşma ve dil gelişimi mevcut olan sekiz yaşındaki hastada nöbet öyküsü ve ailesinde akraba evliliği bulunmamaktadır. Hastalığın genetik sebebinin araştırılmasının detaylı yapılabilmesi için Tüm Ekzom Dizi Analizi yapılmıştır. 
Bu çalışmada Yeni Nesil DNA Dizi Analizi (YND) yöntemi kullanılmıştır. Çalışmada insan genomundaki 60MB'lık ekzom bölgesinin \%90’1 hedeflenerek Agilent Sure Select Human All Exon V6 kiti kullanılarak zenginleştirilmiştir. Zenginleştirilen kütüphane, Illumina yeni nesil dizileme platformunda ortalama 100X kapsama ile dizilenmiştir. Tipik olarak, dizilenen bölgelerin \%97'si >10X'tir. Sonuçların biyoinformatik analizi Burrows-Wheeler Aligner programı ile GRCh37/hg19 genom hizalaması kullanılarak yapılmış olup düşük kapsama alanında kalan bölgeler ve artefakt olma ihtimali olan varyantlar değerlendirme dışı tutulmuştur. Referans veri tabanları olarak ClinVar (http://www.ncbi.nlm.nih.gov/clinvar/)(Landrum et al. 2014), The Human Gene Mutation Database (HGMD) (http://www.hgmd.cf.ac.uk/ac/index.php), CentoMD ${ }^{\circledR}$ (https://www.centogene.com/digital-services/mutation-database-centomd.html), ExAc veritabanı (http://exac.broadinstitute.org/) kullanılmıştır. Değerlendirmede HGMD ${ }^{\circledR}$, ClinVar veya CentoMD ${ }^{\infty}$ de bildirilen hastalıkla ilişkili tüm varyantların yanısıra, ExAc veri tabanında küçük alel frekansı (MAF) \% 1'den daha az olduğu düşünülen varyantlar da göz önünde tutulmuştur. Ayrıca kodlama yapan ekzomların +/- 20 baz yakınındaki intornik bölgeler de analiz edilmiştir. Varyantların değerlendirmesi yapılırken olası tüm kalıtım paternleri, buna ek olarak, ailenin geçmişi ve klinik bilgileri göz önüne alınmıştır. Tanımlanan tüm varyantlar, patojenite ve nedensellik açısından değerlendirilir ve bunlar aşağıdaki sisteme göre sınıflandırılır. Benign veya muhtemelen iyi huylu varyasyonlar hariç, hastanın fenotipi ile ilgili tüm varyantlar rapor edilmiştir.

Tüm Ekzom Dizi Analizi kullanılarak hastalığın genetik araştırılması yapılmıştır. Analiz sonucunda tespit edilen varyantların hastanın klinik bulguları ile olan ilişkisi biyoinformatik yöntemler kullanılarak araştırılmıştır. Tespit edilen tüm ekzomlarında bulunan varyantların filtrelendirilmesi sonucunda hastanın klinik bulgusuyla ilişkili olarak SETBP1 geninde mutasyon saptanmıştır. Bu mutasyon Sanger dizileme ile doğrulanmıştır (Şekil 1).

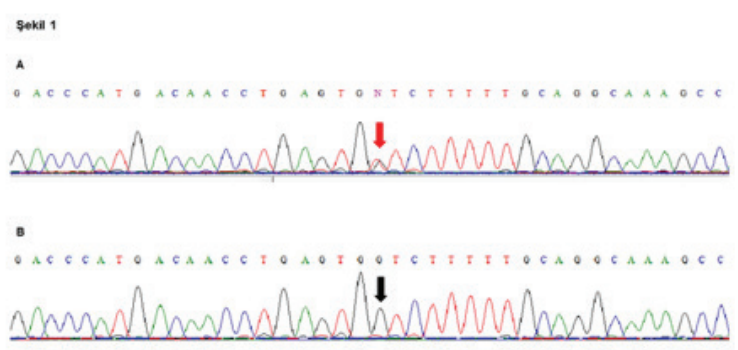

Şekil 1: SETBP1 Geninde Saptanan Mutasyonun Sanger Sekanslama İle Doğrulaması

A: SETBP1 geninde heterezigot c.3515 G>T dönüşümü gösterilmektedir (kırmızı ok). B: Kontrolde c.3515. nükleotit Guanindir (siyah ok).

SETBP1 geninde otozomal dominant heterozigot olarak saptanan c.3515G>T (p.Gly1172Val) varyantı, proteinin 1172. pozisyonda bulunan Glisin amino asidinin Valine dönüşmesine neden olmaktadır (Şekil 2). Sanger dizileme ile doğrulanan bu değişim; ACMG kriterlerine göre klinik etkisi bilinmeyen değişim (Vaient of Uncertainty, VUS, Class III) olarak sinıflandırılmaktadır. Bu varyantın ve literatürde ilişkili olduğu hastalığın bilgileri Tablo 1'de verilmektedir.

\begin{tabular}{|c|c|c|c|c|c|}
\hline \multicolumn{2}{|c|}{ Tablo 1: Mental Retardasyon Tip 29 Sendromuyla İlişkili SETBP1 Geninde Bulunan Yeni Mutasyonun Tüm Ekzom Dizileme Yöntemi İle Analiz Sonucu } \\
\hline $\begin{array}{c}\text { Gen } \\
\text { (transkript) }\end{array}$ & Nükleotid (protein) & Zigosite & dbSNP & $\begin{array}{c}\text { Varyant Sinıflandır- } \\
\text { ması }\end{array}$ & $\begin{array}{c}\text { Hastalık } \\
\text { (OMIM\#, Kalıtım) }\end{array}$ \\
\hline $\begin{array}{c}\text { SETBP1 } \\
\text { (NM_015559.2) }\end{array}$ & $\begin{array}{c}\text { c.3515G>T (p.Gly- } \\
1172 \text { Val) }\end{array}$ & Heterezigot & - & $\begin{array}{c}\text { Etkisi bilinmeyen } \\
\text { değişim (VUS) }\end{array}$ & $\begin{array}{c}\text { "Mental Retardasyon Tip } \\
\text { 29(?)" } \\
\text { OD (616078) }\end{array}$ \\
\hline
\end{tabular}


SETBP1 geni kromozomun 18q12.3 bölgesinde lokalize olup, protein kodlayan 5 ekzom bölgesinden meydana gelmektedir. Bu gen, üç nükleer lokalizasyon sinyaline ek olarak bir ski homoloji ve bir SET-bağlama bölgesi gibi birkaç motifi içeren bir proteini kodlamaktadır (Şekil 2). SETBP1, kromatini daha erişilebilir hale getirmek ve gen ekspresyonunu düzenlemek için histon metilasyonu üzerinde birlikte hareket eden bir grup protein parçasını oluşturan bir DNA bağlayıcı proteindir. Kodlanan proteinin, DNA replikasyonuna katılan SET nükleer onkojenini bağladığı bilinmektedir. Bu gen için farklı izoformları kodlayan çoklu transkript varyantları da bulunmaktadır. Ayrıca SETBP1'in hedef genlerinin gen ontolojisi analizi, bunların viseral organ gelişimi ve beyin morfogenezinin kilit kontrolörleri olduklarını göstermiştir. ${ }^{10}$

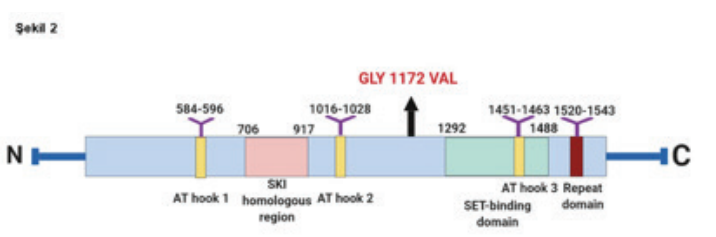

Şekil 2: SETBP1 Protein Domainleri

SETBP1 Proteini üç AT hook bölgesi (584-596, 1.0161.028, 1.451-1.463 amino asitleri), bir SKI homolog bölgesi (amino asitler 706-917), bir SET-binding domaini (amino asitler 1,292-1,488) ve bir tekrar domeni içerir (bir amino asitler 1,520-1,543). Analizimizde tanimlanan mutasyon (1172. pozisyonda bulunan Glisin amino asidinin Valine dönüşmesi ) gösterilmiştir (Siyah ok).

SETBP1 genindeki patojenik varyantlar otozomal dominant kalıtımlı "Mental Retardasyon Tip 29" ve "Schinzel-Giedion Midface retraction sendromu" ile ilişkilidir. Mental retardasyon tip 29 (MRD29); şiddetli zihinsel gerilik, davranışsal zorluklar, konuşma ve motor gecikmeler ve dismorfik yüz özellikleri ile karakterizedir. Schinzel-Giedion sendromu ise; ağır mental retardasyon, ayırıcı yüz özellikleri, iskelet anomalileri, genitoüriner ve böbrek malformasyonları ve kardiyak defektleri içeren multipl konjenital malformasyonlar ile karakterize olup kolayca saptanabilen bir sendromdur. Hastalarda; ayrıca, nöroepitelyal neoplazi başta olmak üzere farklı tümörlerin prevalansı yüksektir. Hastada SETBP1 geninde heterozigot olarak saptanmış olan mutasyon, hastanın verilen klinik bulguları ile ilişki göstermektedir. Sanger dizileme ile doğrulanmış olan bu mutasyonun de novo mu kalıtsal mı olduğunun tanımlanabilmesi için önerilen aile çalışması indeks vakanın ebeveynleri tarafından kabul edilmemiştir.

\section{TARTIŞMA}

Zihinsel engelliliğin risk faktörleri, eğer erken dönemde tanımlanabilirse hastalığın gelişimi önlenebilir. Özellikle beş yaşına kadar olan dönemde beyin gelişimi oldukça hızlı gerçekleşir bu durum bireyin zihinsel fonksiyonlarını doğrudan etkilemektedir. Bundan dolayı zihinsel engelliliğin önemli risk faktörlerinden olan genetik etmenlerin tanımlanması büyük önem taşımaktadır. ${ }^{11}$

Tüm Genom Dizileme teknolojisi ile hastalıklara sebep olan genlerin keşfi ve bu genlerin işlev gördükleri yollakların düzenlenmesi birçok hastalığın tanı ve tedavisinde çı̆̆ır açmıştır. ${ }^{12}$ Genlerin kodlanabilen bölgeleri, ekzomları, yeni nesil dizileme metoduyla dizilenebilmektedir. Genomun yaklaşık olarak \%2'sini ekzomun oluşturduğu tahmin edilmektedir ve bunların da \%85' inin hastalık yapıcı olduğu belirlenmiştir. Tüm ekzom dizileme yöntemi dahil yeni nesil dizileme teknolojilerinin, \%5-10 civarında yalancı pozitiflik oranı vardır. Buna bağlı olarak, yeni nesil dizilemeyle elde edilen klinik açıdan önemli varyantlar, varyantın gerçek pozitif olduğunu belirlemek amacıyla Sanger dizileme yöntemi ile doğrulanması gerekmektedir. Biruni Üniversitesi Genom Merkezi'ndeki Sanger dizileme sistemi, bu varyantların doğrulanması ve yorumlanması için optimize edilmiştir. Test sonuçları; klinik bulgular, aile geçmişi ve diğer laboratuvar verileri bağlamında yorumlanır ve sadece hastanın klinik bulgularıyla ilişkili olan genlerdeki varyasyonlar rapor edilir. Bununla beraber, seyrek polimorfizmler pozitif sonuçlara sebep olabilir. 
Rapor edilmiş varyantlar, hastanın tüm semptomlarıyla ilişkili olacağı anlamına gelmez. Klinik bulguların detayli olarak alınması daha doğru bir değerlendirme açısından önem taşımaktadır. Bulunan varyantların filtrelenmesi, verilen klinik bulgular ışı̆̆ında yapılarak hastalıkla ilişkili olan varyantların doğru saptanması sağlanır. Bu çalışmada hastanın SETBP1 geninde heterozigot olarak saptanmış mental retardasyon tip 29' la ilişkili olan yeni mutasyon, yapılan Sanger çalışmasıyla doğrulanmıştır ve c.3515G>T (p.Gly1172Val) mutasyonu hastanın verilen klinik bulguları ile ilişkisi olduğu gösterilmiştir. 
Sakarya Tip Dergisi 2019;9(4):715-720

ALAGÖZ ve Ark. Mental Retardasyon Tip 29: SETBP1 Geninde Yeni Mutasyon Tanımlanması

\section{Kaynaklar}

1. DeSilva M, Munoz FM, Mcmillan $M$, et al. Congenital anomalies: Case definition and guidelines for data collection, analysis, and presentation of immunization safety data. Vaccine. 2016;34(49):6015-6026.

2. Huang J, Zhu T, Qu Y, Mu D. Prenatal, perinatal and neonatal risk factors for intellectual disability: A systemic review and meta- Analysis. PLoS One. 2016;11(4):1-12.

3. Nemerimana M, Chege MN, Odhiambo EA. Risk Factors Associated with Severity of Nongenetic Intellectual Disability (Mental Retardation) among Children Aged 2-18 Years Attending Kenyatta National Hospital. Neurol Res Int. 2018.

4. Maria Puiu, Simona Dumitriu, Adela Chiriță-Emandi, Raluca Grădinaru and Smaranda Arghirescu The Genetics of Mental Retardation, Genetic Disorders, Maria Puiu, IntechOpen. January 9 th 2013.

5. Antonarakis SE, Van Aelst L. Mind the GAP, Rho, Rab and GDI. Nat Genet 1998; 19: 106-108.

6. Higgins, J. J., Rosen, D. R., Loveless, J. M., Clyman, J. C., Grau, M. J. A gene for nonsyndromic mental retardation maps to chromosome 3p25-pter. Neurology 55: 335-340, 2000.

7. Al-Amri, A., Al Saegh, A., Al-Mamari, W., El-Asrag, M. E., Ivorra, J. L., Cardno, A. G., Inglehearn, C. F., Clapcote, S. J., Ali, M. Homozygous single base deletion in TUSC3 causes intellectual disability with developmental delay in an Omani family. Am. J. Med. Genet. 170A: 1826-1831, 2016
8. Poirier, K., Lebrun, N., Broix, L., Tian, G., Saillour, Y., Boscheron, C., Parrini, E., Valence S., Saint Pierre, B., Oger, M., Lacombe, D., Genevieve, D., and 23 others. Mutations in TUBG1,DYNC1H1, KIF5C and KIF2A cause malformations of cortical development and microcephaly. Nature Genet. 45: 639-647, 2013. Note: Erratum: Nature Genet. 45: 962 only, 2013.

9. Hoischen A, Van Bon BWM, Gilissen C, et al. De novo mutations of SETBP1 cause Schinzel-Giedion syndrome. Nat Genet. 2010;42(6):483-485.

10. Piazza R, Magistroni V, Redaelli S, et al. SETBP1 induces transcription of a network of development genes by acting as an epigenetic hub. Nat Commun. 2018;9

11. Ramiah R Vicker R.R. and Gibson J.S. A Review of the Genomic Analysis of Children Presenting with Developmental Delay/Intellectual Disability and Associated Dysmorphic Features. Cureus. 2019;

12. Seripa, D., Pilotto, A., Panza, F., Matera, M. G., and Pilotto, A. Pharmacogenetics of cytochrome P450 (CYP) in the elderly. Ageing Res. Rev. 2010;9:457-474. doi: 10.1016/j.arr.

13. Bonnefond A, Philippe J, Durand E, Dechaume A, Huyvaert M, Montagne L, et al. Whole-Exome Sequencing and High Throughput Genotyping Identified KCNJ11 as the Thirteenth MODY Gene. Brusgaard K, editor. PLoS ONE. 2012;7: e37423. pmid: 22701567 